DOI: $10.20472 / S S .2016 \cdot 5 \cdot 3.002$

\title{
LABOR MIGRATION TO THE CZECH REPUBLIC
}

\section{SARKA PRAT}

\section{Abstract:}

The reasons for increasing interest in studying the links between migration and economic development are many, but the most important is undoubtedly the rising absolute number of immigrants in economically developed countries, increasing the amount of remittances sent for last 10-15 years and an aging population in developed countries.

This article deals with labor migration in the Czech Republic, which greatly affects not only the labor market, but also the development of the country. Although the topic is very broad, which can hardly be described exhaustively due to limited space, the primary objective of the paper is to give a comprehensive view on the selected issue.

The secondary objective of the paper is not only in analysis of the consequences that come along with the process of labor migration, but also in the preparation of forecasts which reflect the possible development of labor migration in the future. The paper analyzes the development of immigration to the Czech Republic from 1995 to 2013 and look at the impacts of labor migration on the labor market, which may occur for example in the form of risks of brain drain or demofigureic changes. The important part of the paper is a regression and correlation analysis which demonstrate the influence of the migration on GDP, wages, innovations and tax revenues.

\section{Keywords:}

labor migration, labor market, immigration, emigration, Czech Republic

JEL Classification: J15, J21, J33

\section{Authors:}

SARKA PRAT, University of Economics, Prague, Czech Republic, Email: sarkaprat@seznam.cz

\section{Citation:}

SARKA PRAT (2016). Labor Migration to the Czech Republic. International Journal of Social Sciences, Vol. V(3), pp. 17-40., 10.20472/SS.2016.5.3.002

The article was written within the project IGA No.30 / 2016 Monitoring and evaluation of the economic and social development of the regions of the EU and the Czech Republic: methodology and practical applications. 


\section{Introduction}

The migration process might be considered as a process of a constant development in the world that always changes. According to Stojanov, Strielkowski a Drbohlav (2011), the issue of migration is as old as the history of humanity, while migration flows represent one of the most important dynamic features of all enormous civilisations. People have been moving from the ancient times because of various reasons and causes. As Zapadlo assumed (2010), one of the first reasons of those movements was the aim to find a safe place to live, that later changed into the searching for a place with better life conditions and job opportunities. Moreover, the strong reasons of migration were the involuntary expulsion, political repressions and human rights abuses. Thus, over the centuries, the phenomenon of the migration has gained its momentum and importance. Nowadays, the movement of humanity has an impact on the development of infrastructure, means of transport and rapid transmission of information; furthermore, it shows that people migrate not only inside the borders of a country but in the entire continents. According to the estimates of the United Nations Population Division (UNDP, 2013), the amount of crossborder migrants in 2012 rose to 214 million. Due to the significant population growth, the share of migrants in the global population has not changed much, only $0.2 \%$ since 2000 (UNPD, 2013). Likewise, it increased over 64 million people in the same period. For today, immigrants make up 3.1\% of the world's population (Ministry of Foreign Affairs, Czech Republic, 2014). If all the migrants went to an uninhabited land, it would become the fifth most populous country in the whole world.

As it was reported by Stojanov and Novosák (2008), the relationship between migration and development are extremely complex and sensitive to specific factors for each area; therefore, it is rather complicated to figure all benefits and limitations in general. The departure of educated people abroad might be perceived negatively by some states (especially by countries with the smallest populations); while it might be one of the major development strategies with well-organized migration infrastructure in other states.

Based on the idea by Drbohlav (2011), the directions of migration flows are significantly affected by the level of development of emigration and immigration areas. Generally, because of the lack of targeted immigration policy or such called major "push" factors (eg. political discrimination, environmental changes, etc.), the migration processes might be traced in two basic tendencies.

While qualified people emigrate from the countries where their education and skills are not fully appreciated or awarded (e.g. Doctors), less skilled migrants are mostly recruited from countries where their education and skills can be greatly appreciated but their achievement is extremely difficult (low capacity of universities, too high costs, complicated availability etc.). Both of those trends lead to a common direction of international migration, from developing countries to economically developed. 
Migration is considered as one of the most important global challenges. According to the Prochazkova Ilinitchi (2010), it acts as an accelerator of globalization; however, it is supported and stimulated by other globalization processes. People migrate because of a variety of reasons, the most common of them is to improve their life conditions. Since migration flows are heading from poor countries to developed ones, there is a necessity to track these flows, influence and regulate them. International migrants are one of the strongest and most troubled effects, because their permanent presence in a country might change the attitude of a particular country to the whole nation.

How Zolberg (1999) and Castles (2004) pointed out, the economic distance between the global North and the South has become so huge to create an inexhaustible supply of potential migrants. The abyss is increased by the forces of globalization, which attract the population of the Third World by the benefits of modern consumption in developed countries. Nevertheless, it does not provide the resources that are needed to make a progress in the developing countries. Meanwhile, in developing countries the growing thirst of a labor force willing to perform hard and lower-paying menial jobs ${ }^{1}$ in the developed countries creates a powerful magnet for migrants from less developed countries.

While most economic theories tend to favor the benefits of free movement of population, development studies have a tendency to consider migration as a forced process by some circumstances, such as the poverty population in developing countries, conflicts and civil wars or other instability (De Haan 1999). Therefore, the migration at this pattern is often seen as the last possible option to survive for poor, with an increased emphasis on the excessive exploitation of resources and territory targets of migration. The issue of international migration is recognized as a global problem that should be addressed (eg. Martin, Widgren, 1996; Martin, Widgren 2002), especially in terms of the impact on the labor market.

General patterns of migration, Vavra (2014) set in his work as follows:

- The majority of migrants prefers shorter distances.

- Migrants who travel a greater distance focus on the commercial and industrial centers.

- Every migration stream generates a migration counter.

- Population growth of large cities happens because of the influx of migrants rather than the natural growth of the indigenous population.

- The volume of migration has grown along with the development of industry, trade and transport development.

\footnotetext{
${ }^{1}$ that the native population systematically avoids
} 
- The majority of migrants comes from rural areas and heads to industrial and commercial centers.

- The majority of migration factors has economic character.

- Migrants who move into target areas, leaving behind "empty spaces", which are filled with other migrants from other areas.

- Women, unlike men, prefer to emigrate to the far distances.

- The average age of migrants is $20-34$.

The concept of migration is closely related to the concept of migration decision making. According to the basic microeconomic model, people decide if they should emigrate or not based on whether the marginal benefit of migration outweighs its costs. After a certain time, the benefits of increased rate of migration become as an investment, more precisely, investment in human capital. The concepts of human capital might be viewed from various angles. While some authors, among them Prof. Ing. Robert Holman, PhD., claims that the basic human capital is education, in the case of migration, it might be understood rather as productive abilities of the individuals. To explain the migration decision process, Human Capital model of migration ${ }^{2}$ can be used. Based on this model, the reasons of migration rate decreases with increasing age might be explained. Although based on microeconomics factors migration decisions might be clarified, a majority of economic theory ignores one of the main reasons of migration, family reunification. The benefits of migration and migration costs are mostly limited by economic variables. Migration costs are not only financial expenditures that are required for the implementation of the path but also the opportunity costs; thus, the benefits that migrants had are the second-best opportunities. It is possible to consider the overall benefits; therefore, its overall satisfaction remains in the country. At the same time the costs of migration might also include the cost of separation from family or friends and contacts (phone calls, trips to their homeland). Likewise, the benefits are not only associated with higher wages but also with the improvement of living standards such as environmental health, better education, etc. If a person decides between several countries to migrate, he most likely would choose that one which offers him a higher net profit. ${ }^{3}$

Mathematical formula shows the migration decisions might be expressed as follows:

$$
P V_{a b}=\sum_{t=1}^{T} \frac{U_{b}^{t}-U_{a}^{t}-C_{a b}^{t}}{(1+r)^{t}}>0
$$

\footnotetext{
2 It was created in the 60th to 70th years of the 20th century

${ }^{3}$ DE JONG, G. F. a GARDNER, R.W. Migration decision making: multidisciplinary approaches to microlevel studies in developed and developing countries. p. 17
} 
where

$\mathrm{PV} a b=$ the present value of net migration from country A to country $\mathrm{B}$,

$U_{b}=$ expected benefits of the country $b$

$\mathrm{Ua}_{\mathrm{a}}=$ expected benefits of the country a

$\mathrm{a}=$ country of origin

$\mathrm{b}=$ target country

$r=$ interest rate $(0 \leq r \leq 1)$

$\mathrm{T}=$ life expectancy

$\mathrm{Cab}=$ costs associated with migration from country A to country $\mathrm{B}$

A man decides to migrate only if there is the difference between the expected benefit which would have earned in the country to which he would migrate, and the expected benefit to the country from which he emigrates and costs associated with migration is greater than zero. At the same time, we must take into account the effect of interest rates in order to compensate for the value of current and future consumption. ${ }^{4}$ Although economic theory takes into account only economic variables, ultimately, they are more objective than uneconomic ones. This statement can be endorsed by the fact that each person perceives the non-monetary factors differently. A good example is a geofigureic location of the target country in the sub-polar climate, which is appreciated especially by the younger generation who wants to enjoy winter fun, but not the generation of older people who may suffer from rheumatoid arthritis. ${ }^{5}$

\section{Development of migration in the Czech Republic}

The issue of international migration and its consequences in the Czech Republic topical arose after 1990. The emigration and immigration in the Czech Republic began to gain its momentum after the fall of the Iron Curtain and the collapse of the communist bloc. Moreover, there was no previous experience to cope with such an influx of migrants. Along with the entry of the Czech Republic into the EU, the migration and asylum policy had to be changed to conform to the norms of the European Union.

Foreign workers in the Czech Republic might be divided into two main streams - the foreigners with a permanent residence permit and foreigners with a temporary residence permit (visa over 90 days for the purpose of employment or business). Foreigners who

${ }^{4}$ DE JONG, a GARDNER, p. 18

5 ČESKÁ LÉKAŘSKÁ SPOLEČNOST. Revmatoidní artritida In: Doporučené postupy pro praktické lékaře. 
had a permanent residence did not form a significant group of people in the labor market for long. Despite their number grew over the years, by the end of 2005, the number of foreigners with permanent residence were less than 1\% of the workforce in the Czech Republic (Ministry of Labor and Social Affairs, 2011). A significant role in the labor market was occupied by foreigners with a temporary residence permit:

a) Foreigners with work permits - permission to employ the foreigner worker is allowed at the request of the employer, and only if the domestic labor market does not have suitable candidates for the particular job. The number of jobseekers in some cases might be restricted by quota, which determines how many foreigners from certain countries might be employed in the Czech Republic in a given year.

b) Slovak citizens registered by labor offices - If foreigners with work permits are not citizens of the Slovak Republic, their number is determined by supply and demand on the domestic labor market.

c) foreigners with trade license - This group of foreigners is bound by the general legal conditions that define the business in the Czech Republic. If these foreigners carry out business in the Czech Republic through a legal representative, they are obliged to apply for a residence permit.

\section{Migration flows between 1990-2003}

The number of foreigners gradually increased in the nineties. Between 1994 and 1999 it was even doubled (CSO, 2013). The Act no. 326/1999 Coll. regarding the stay of foreigners came into force on 1 January 2000. The entry and residence rules of the majority of foreigners in the Czech Republic were significantly tightened, which caused a perceptible decrease in the growing number of immigrants. Some of the provisions of this Act were mentioned in the amendment in force since 1 July 2001, which resulted in a renewed slight increase in the number of settled foreigners. Thus, the period, except for 2001, might be labeled as positive migration balance. 
Figure 1: Migration balance 1990 - 2005.

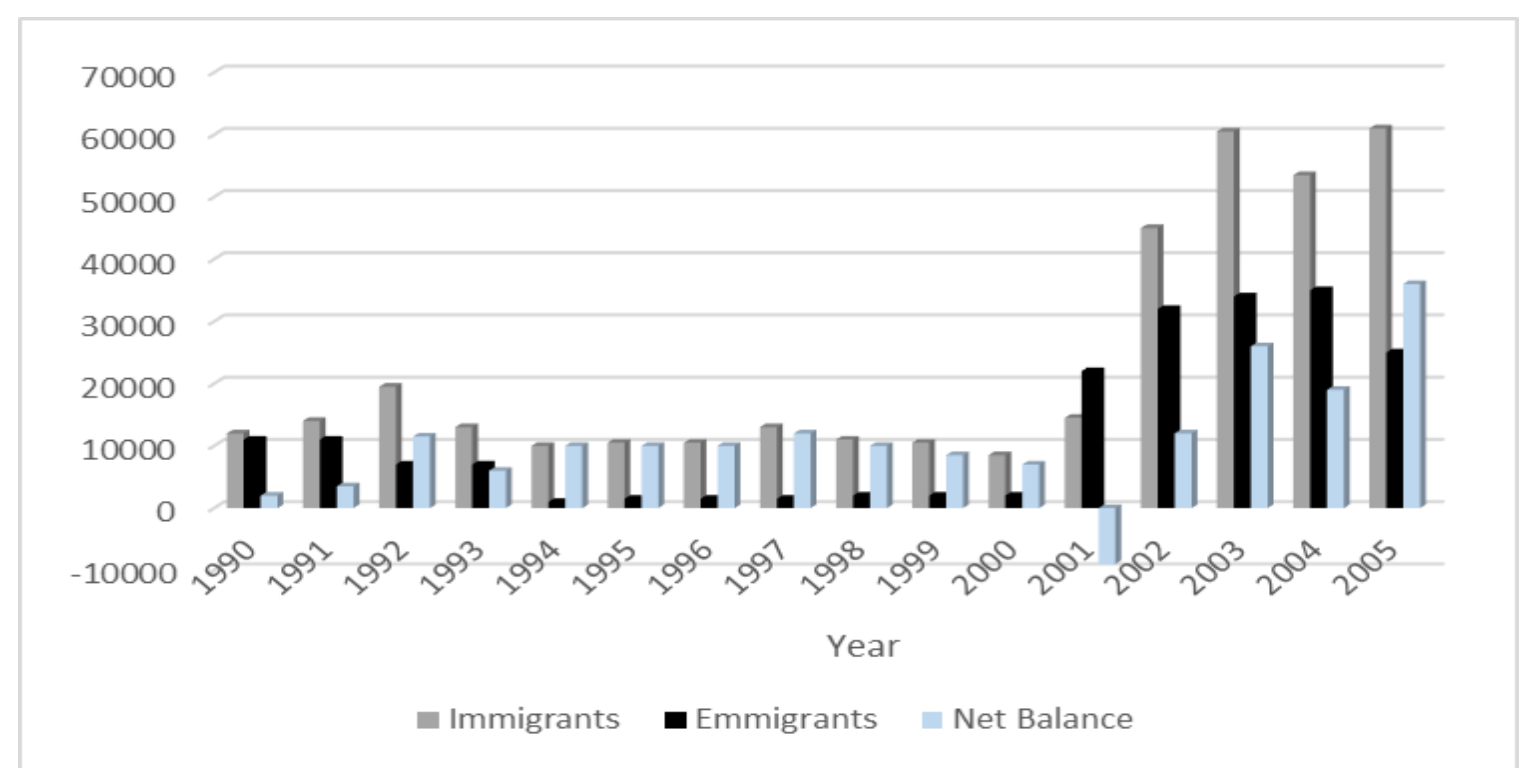

Source: Own proceeding based on data from Čsú.

According to France (2014) in the early 90s, the Czech Republic (then Czechoslovakia) was an attractive country to migrate, due to the political and economic changes in the country towards the establishment of a democratic political system with a market economy. How Baršová (2005) claimed, the aim of immigrants was not only a temporary labor migration but also was as permanent immigration, especially in Prague. According to France (2014), the migratory movements scooped the huge dimension in 1990-1992 and the situation stabilized only after 1993 when the annual number of immigrants settled around 10,000 people (CSO, 2013). Nevertheless, this trend was banished to the end of the century, and only since 2001 the country began to change, and a sharp gain intensity of migratory movements happened. As Horakova (2005) assumed, "External migration Czech Republic gained a total of 131400 inhabitants in the period 1990 to 2000; emigration lost, according to official records, of 43700 inhabitants. For the period 20012005 migration added 233000 people to the population".

While the share of foreigners with a temporary residence permit in the labor force was only $1.7 \%$ in 1994, by the end of 2003 this share grew up to $3.2 \%$ (CSO, 2015). According to Horakova (2005), the reasons for that percentage growth was not a friendly approach to labor migration, but they were caused by government's fears of a shortage of skilled labor in the future rather than the needs of the domestic labor market. 
As Horakova (2004) pointed out, it must be remembered that the employment of foreigners (as an aggregate) covers only labor activity of foreigners with long-term residence in the Czech Republic. Foreigners with permanent residence permits are not included in the analysis because their legal status is not different from that the citizens of the Czech Republic have. While till 1993 the most significant component were the foreigners with work permits, since 1994 the primacy was taken by Slovak citizens registered by labor offices. Then at the end of 2003, they had a share of $35 \%$ of the total economically active foreigners in the Czech Republic, and they were in the second place, only the foreigners with trade licenses had $2 \%$ more. The third place with $28 \%$ belongs to the employees with work permits.

\section{Figure 2: Foreign employees in the Czech Republic}

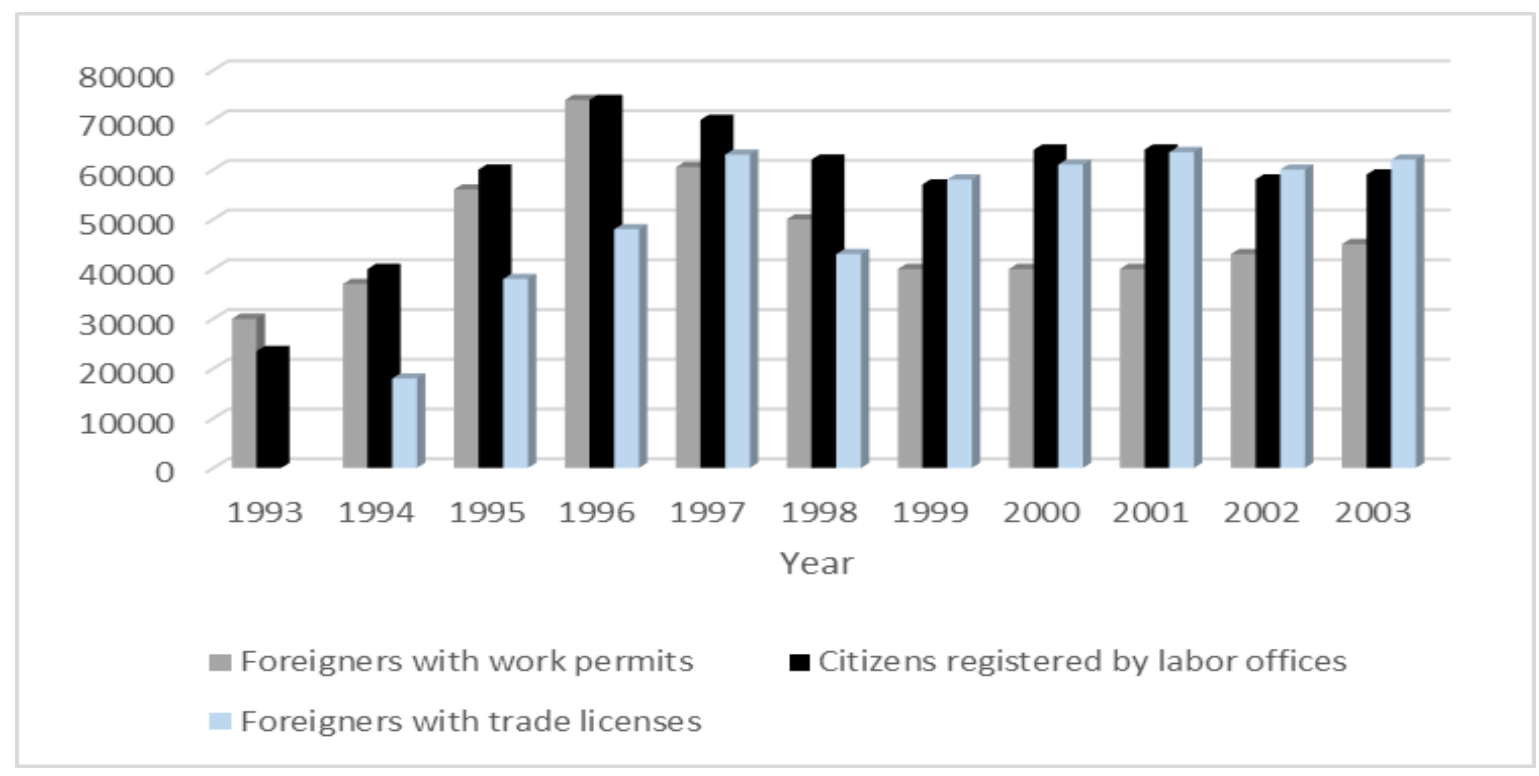

Source: Own proceeding based on data from Ministry of Industry and Trade.

During the reporting period, in order to avoid major countries on the Czech labor market, dramatic changes started. Changes might be observed regarding the number of immigrants from various countries during the specified years. The Czech Republic labor market was attractive for citizens of economically weaker countries during the reporting period. The dominant position on labor migrants in the Czech Republic (year 2003) with a share of 39\% were occupied by Slovak citizens. According to Franc (2014), Slovakia is one of the most historically significant source countries for labor migrations in the Czech Republic, because: "The geofigureical, cultural and linguistic proximity, the close connections, similar economic environment and favorable legislative conditions for employing Slovaks have created pleasant conditions for increasing their number on the Czech labor market". The number of economically active Slovaks reached its peak in 
1996 (72 244 people), and since 2001 there was a significant decline. In accordance to Winkler and Žižlavského (2004), "The decline in registered employment of Slovak citizens could be caused partly by improving the accounting registration of Slovak citizens in the Czech labor offices as a result of tightening and increased checks on prospective employees in Slovak labor offices, which prevented the abuse of the unemployment allowance to those jobseekers who simultaneously worked in the Czech Republic. Another reason might be a positive expectation of Slovak citizens associated with the entry of Slovakia into the European Union, which would lead to the stabilization of Slovak labor force on the domestic labor market".

The second place in the representation of foreign workforce on the Czech labor market was given to Ukraine, which brought a share of $25 \%$ (Eurostat, 2013). In this case, Franc explains (2014): "The Ukrainian economy after the collapse of the Soviet Union was going through a difficult transition period, that created pleasant conditions to make jobs for Ukrainian citizens in the Czech Republic". According to Winkler and Žižlavského (2004), Ukrainian migration has undergone significant upheavals in the structure of employment. The agreement for the employment of Ukrainians in the Czech Republic in 1996, which allowed to set annual quotas for the number of employment permits that might be issued to Ukrainians, caused only in the years 1996 to 2002, decreased the number of valid work permits Ukrainians by 22,000 . On the other hand, a significant part of Ukrainians moved into the realm of business and the number of holders of the trade license issued to Ukrainians grew by 16,000 in the same period.

The third position as the most important source country is held by Vietnam with the share of $13 \%$. Vietnamese, whose labor migration into the Czech Republic had a history, even before 1989, saw an opportunity to improve their economic situation. Brouček (19) states: "They come and come here for in search of better earnings than they had in Vietnam. They do not migrate because of a desire to change the cultural environment of the Czech Republic or something else. They are coming to sacrifice their life for material gain in the near future. There are three reasons for Vietnamese to do business and to live in the Czech Republic: financial stability of a family, child secure, and care of parents who are in Vietnam." The vast majority of them applied in business, the maximum number of Vietnamese traders was dated 1997. Nonetheless, the number of Vietnamese immigrants declined 4700 people in the period of 1997-2002. Although the amount of economically active people in the years 1997 - 2002 decreased, during the same period the number of residence permits of Vietnamese in the Czech Republic increased about 19000.

The fourth and last country in statics dealing with migration flows is Poland, with a $5 \%$ share. Unlike the Ukrainians, a considerable part of the Poles in the Czech labor market are employees, that issue Franc (p. 15-16) explains: "The Poles used to be compared to other foreigners employed mostly on the basis of work permits issued under business contracts by Czech and Polish companies. Also, this is a reason for the lower incidence of illegal employment among Poles, for example, compared with the Ukrainians. " 
The list of the source regions of the labor migration might be completed with Bulgaria, Russia, Germany, the United States and Moldova. These countries did not follow the top four countries with significant impact of foreigners on the labor market in the Czech Republic. Nevertheless, in the context of the common labor market of the European Union, they have importance to the Czech Republic. Moreover, they make up almost half (49\%) of total foreign workforce operating in the Czech Republic. At the end of 2003 to $45 \%$ out of $49 \%$ were labor migrants from the countries EU-10. Specifically, the aforementioned Slovakia, whose share accounted for $89 \%$ of total migration from EU-10 and Poland with the remaining share of $11 \%$. Labor migration from the EU-15 are only $4 \%$ and consists of primarily residents of Germany, the UK, France, Austria and Italy.

\section{Figure 3: Labor migration from the EU-10 and EU-15 in 2003}

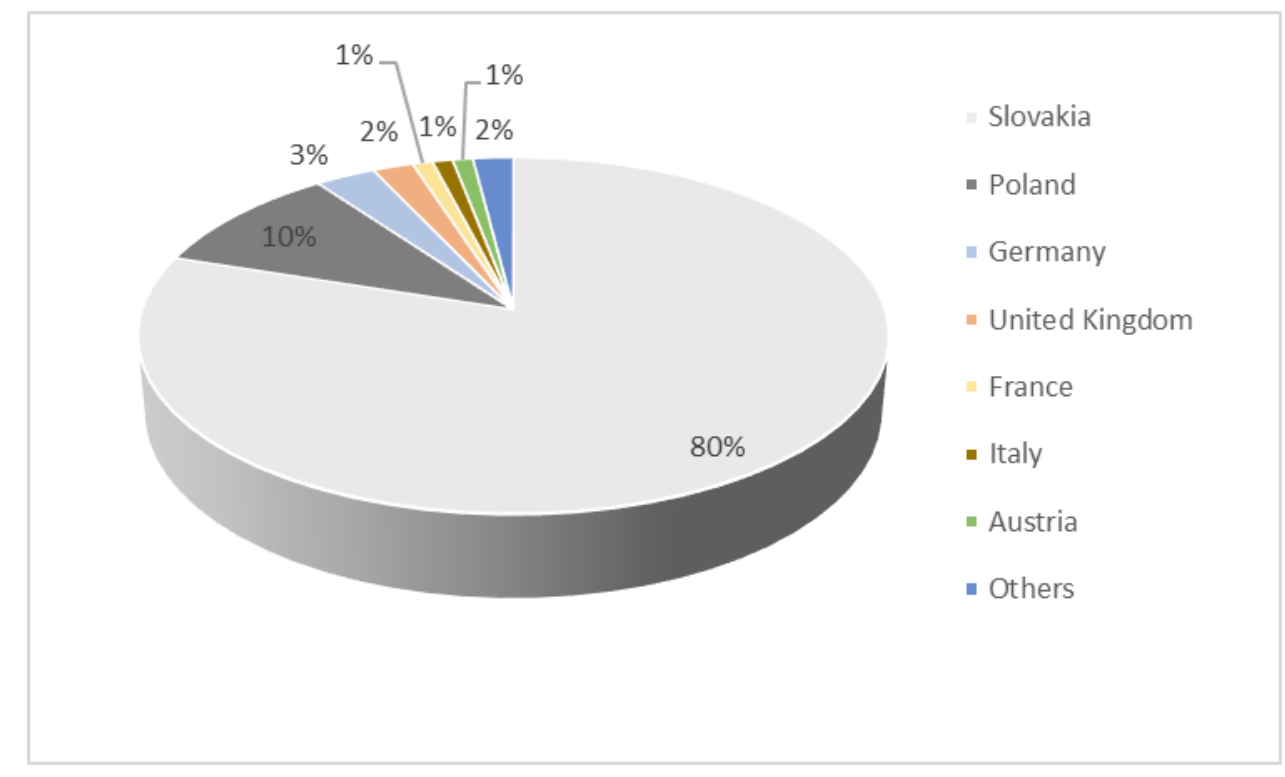

Source: Own proceeding based on data from Ministry of Industry and Trade.

Professional development has not been noted over the years 1990 - 2003. The majority of the migrants on the Czech labor market carries workers' occupation. Just in the years $1993-2003$, the issued working permits for manual laborers consisted of 75 to $85 \%$ of all working permission.

Those workers mostly came from Central and Eastern Europe. At the end of 2003 the labor offices in the Czech Republic reported the following qualifications of foreign workers: $44 \%$ are skilled workers, $36 \%$ of assistants, $12 \%$ of workers at places that were required to have higher education, and $9 \%$ in jobs were required to have full secondary education. As a typical profession for Slovak citizens and foreigners with work permits are 
given follows: miner, seamstress, construction worker, assembly worker, mason, assistant laborer, laborer in electrical engineering, locksmith, handling worker, laborer in industry and welder (Horakova (p.10)).

\section{Migration flows between $2004-2010$}

In 2004 the Czech Republic joined the European Union and the migration increased on its territory. The big changes occurred in emigration rather than immigration. Figure 4 represents the positive migration balance in the period between 2004 to 2010. Also, it might be added that Prague is the most frequent destination for immigrants in the Czech Republic.

Figure 4: External migration of foreigners 2001 - 2010.

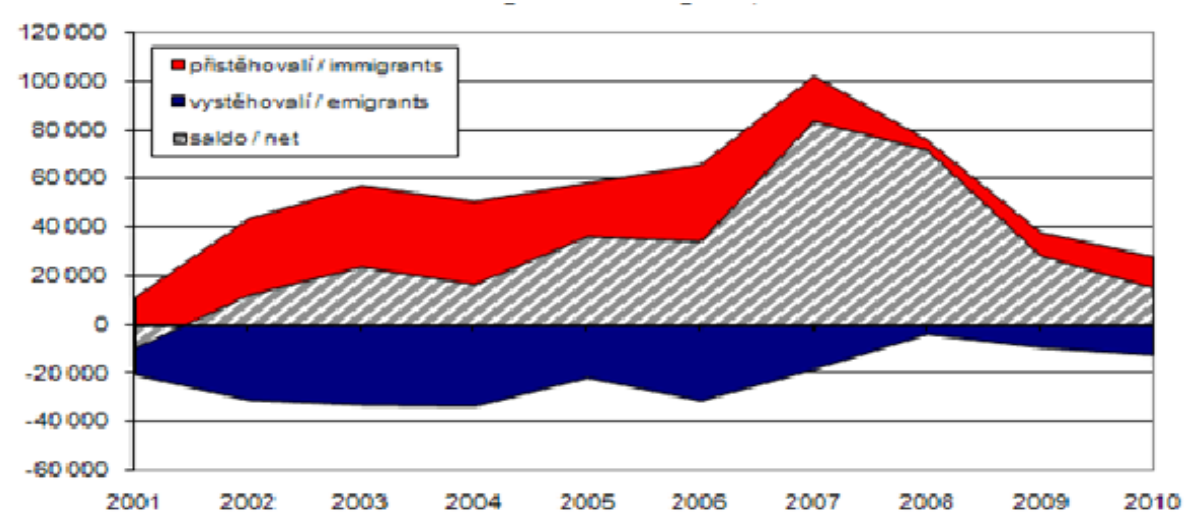

Source: Adopted from the Czech Statistical Office, 2013.

With the Czech Republic's accession to the EU (2004), there was created a new category of residence. Additionally, to a permanent residence and a visa lasting over 90 days there were distinguished also long term stays (stays following after the visas over 90 days) and temporary residence for EU citizens and their family members.

Between 2001 - 2008 the tendency regarding the number of foreigners legally residing in the country continued. In 2008, the Czech Republic Directorate of Alien Police recorded about 438000 foreigners, 39\% of whom were foreigners a with permanent residence. Since 2009, because of the consequences of the economic crisis and ongoing recession, the number of foreigners living in the Czech Republic was declining. Since 2001, numbers of foreigners who in the Czech Republic gained permanent residency is constantly growing. This trend is visible even in times of economic crisis and recession, i.e. between 2009 - 2010. By 2010, a total of 188952 foreigners with permanent residence were registered in the Czech Republic, that is about 119136 more than it was in 2001. Furthermore, the numbers of foreigners with other types of residency, i.e. with visas over 90 days, long-term and temporary residence, more or less follow the trend of 
the overall development of foreigners. Thus, a significant decline is seen in the years 2008 - 2010 (about 30035 persons to 235339 in 2010).

Figure 5: Foreigners with permanent and long-term residents over 90 days.

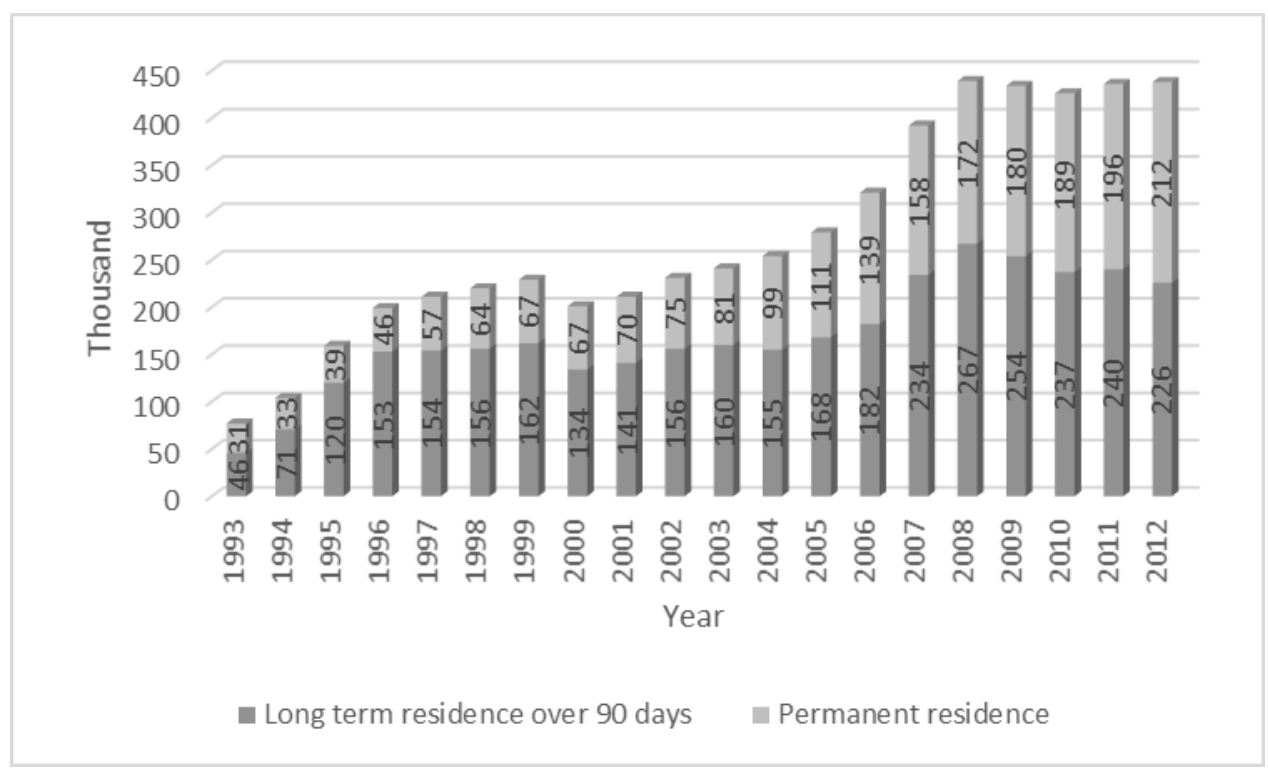

Source: Own proceeding based on Čsú data.

Following table represents development of foreigners with a permission for a permanent residence in the Czech Republic. Although immigration development in the Czech Republic has undergone ${ }^{6}$ many changes in terms of source countries of immigrants, there were only percentage changes.

Table 1: Development of foreigners with a permission for a permanent residence in the Czech Republic 2004 - 2010

\begin{tabular}{|l|l|l|l|l|l|l|l|}
\hline & $\mathbf{2 0 0 4}$ & $\mathbf{2 0 0 5}$ & $\mathbf{2 0 0 6}$ & $\mathbf{2 0 0 7}$ & $\mathbf{2 0 0 8}$ & $\mathbf{2 0 0 9}$ & $\mathbf{2 0 1 0}$ \\
\hline Population of the Czech Republic & $\begin{array}{l}10220 \\
577\end{array}$ & $\begin{array}{l}10251 \\
079\end{array}$ & $\begin{array}{l}10287 \\
189\end{array}$ & $\begin{array}{l}10381 \\
130\end{array}$ & $\begin{array}{l}10467 \\
542\end{array}$ & $\begin{array}{l}10506 \\
813\end{array}$ & $\begin{array}{l}10532 \\
770\end{array}$ \\
\hline $\begin{array}{l}\text { Foreigners which are included into } \\
\text { population of the Czech Republic* }\end{array}$ & 193480 & 258360 & 296236 & 347649 & 407564 & 425758 & 417887 \\
\hline Permanent residents & 99467 & 110598 & 139185 & 157512 & 172191 & 180359 & 188952 \\
\hline Asylums & & 1799 & 1887 & 2030 & 1933 & 2097 & 2132 \\
\hline Temporary EU/ long-term residence & 92390 & 145963 & 155164 & 188107 & 233440 & 243302 & 226803 \\
\hline \% of population & 1,90 & 2,52 & 2,88 & 3,35 & 3,89 & 4,05 & 3,97 \\
\hline
\end{tabular}

${ }^{6}$ Since the end of the last phase 


\begin{tabular}{|c|c|c|c|c|c|c|c|}
\hline Annual index & 0,99 & 1,34 & 1,15 & 1,16 & 1,16 & 1,04 & 0,98 \\
\hline $\begin{array}{l}\text { Population of the Czech Republic and } \\
\text { remaining foreigners }\end{array}$ & 10283014 & $\begin{array}{l}10272 \\
830\end{array}$ & $\begin{array}{l}10314 \\
296\end{array}$ & $\begin{array}{l}10427 \\
826\end{array}$ & $\begin{array}{l}10499 \\
476\end{array}$ & $\begin{array}{l}10515 \\
655\end{array}$ & $\begin{array}{l}10541 \\
306\end{array}$ \\
\hline Total number of foreigners & 255917 & 280111 & 323343 & 394345 & 439498 & 434600 & 426423 \\
\hline Visa over 90 days & 62437 & 21751 & 27107 & 46696 & 31934 & 8842 & 8536 \\
\hline Permanent residence $(\%)$ & 38,9 & 39,5 & 43,0 & 39,9 & 39,2 & 41,5 & 44,3 \\
\hline Valid asylum (\%) & 0,6 & 0,6 & 0,6 & 0,5 & 0,4 & 0,5 & 0,5 \\
\hline $\begin{array}{l}\text { Permission of residence (except for the } \\
\text { permanent ones; \%) }\end{array}$ & 36,1 & 52,1 & 48,0 & 47,7 & 53,1 & 56,0 & 53,2 \\
\hline Visa over 90 days (\%) & 24,4 & 7,8 & 8,4 & 11,8 & 7,3 & 2,0 & 2,0 \\
\hline
\end{tabular}

Source: Own proceeding based on Čsú data.

Foreign workforce employed in the Czech Republic ${ }^{7}$ is traditionally represented by immigrants from Slovakia and Ukraine, but also workers from Vietnam and Poland. ${ }^{8}$

\section{Figure 6: The number of employed foreigners}

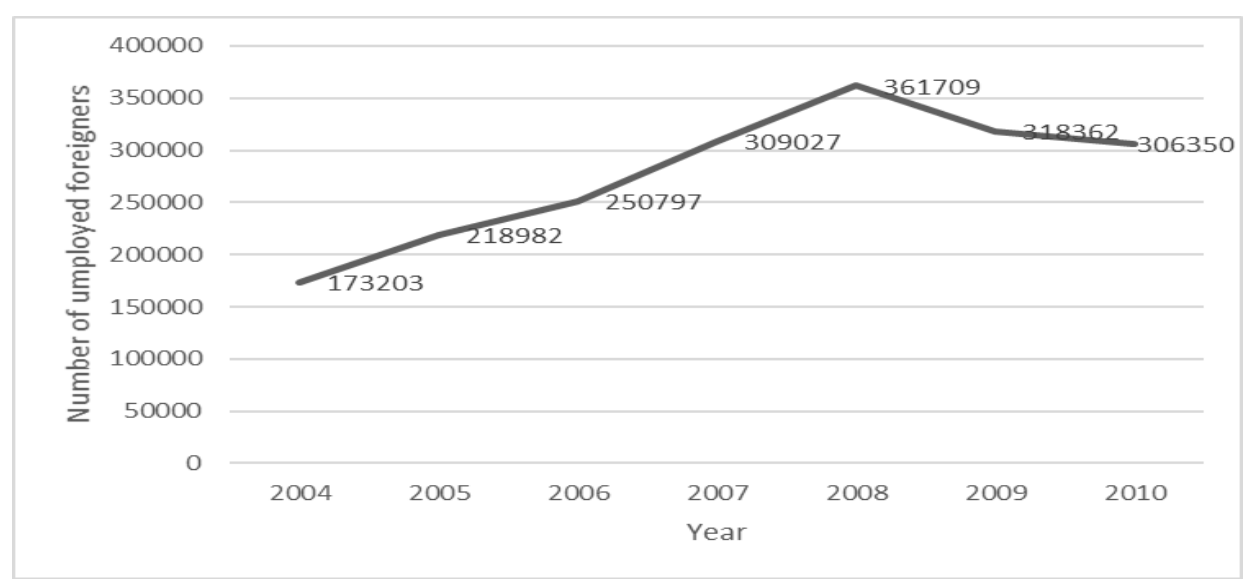

Source: Own proceeding based on ČSÚ data.

Although the Czech Republic implemented a program to get highly skilled workers in 2003, the majority of labor immigration to the Czech Republic remains in blue-collar occupations. For example, at the end of 2006, the biggest share in a professional structure was dominated by foreign workers employed as the craftsmen, skilled manufacturers, processors and assistants $(28 \%)$, followed by unskilled auxiliary workers $(27 \%)$ and workers operating machinery and equipment (16.9\%). With a distance, the other significant groups were operational workers in service and trade $(5.1 \%)$, clerks

\footnotetext{
7 as of 31.12 .2010

${ }^{8}$ Pořízková, H. Analýza zahraniční zaměstnanosti v České republice (p.26)
} 
(3.4\%) and skilled workers in agriculture, forestry and fishing (1.4\%). Professions that require the highest qualification consists of scientists and intellectual workers $(7.7 \%)$, legislators, senior officials and managers (3\%), and last but not least, technicians and associate professionals $(7.5 \%){ }^{9}$

\section{Development of migration from 2011 to the present}

In 2010, the number of foreigners living in the Czech Republic continued to decline. By the end of the year 2010, the Directorate of the Foreign Police and Ministry of Interior in the Czech Republic registered a total of 427291 foreigners, of which 188952 foreigners were with permanent residence and 238339 foreigners were with some type of long-term residents over 90 days. Already in 2010, the most foreigners were citizens of Ukraine (134 281, 31\%), followed by Slovaks (71 780, 17\%), Vietnamese (60 289, 14\%), Russians (31 807, 7\%), Poles (18 242, 4\%) and Germans (13 871, 3\%). While the number of citizens of Slovakia, Vietnam and Poland declined, the number of Russians grew. The number of Germans remained more or less at the same level as in the previous year.

Table 2: Number of foreigners in the Czech Republic (2011 - 2012)

\begin{tabular}{|l|l|l|l|}
\hline \multirow{2}{*}{ Year } & \multicolumn{2}{|c|}{ Type of residence } \\
\cline { 2 - 4 } & Total & Permanent residence & Long term residence \\
\hline $\mathbf{2 0 1 1}$ & 434153 & 196408 & 237745 \\
\hline $\mathbf{2 0 1 2}$ & 435946 & 212455 & 223491 \\
\hline
\end{tabular}

Source: Own proceeding based on ĆSÚ data.

In the last few years, foreigners form about $4 \%$ of the Czech population. The most attractive destination is Prague, and the least is Opava. In the capital of the Czech Republic, 14 out of 100 inhabitants are foreigners. At the end of 2012, $438000^{10}$ foreigners lived in the Czech Republic legally. About 212000 of them had a permanent residence permit, others had permanent residence permits over 90 days. "Most people are heading to the Czech Republic from Ukraine," says Daniel Chytil from the CSO. Authorities registered 124300 Ukrainians, 43\% of foreigners living in the Czech Republic who are from the countries outside the European Union.

The second largest group are the Slovaks ${ }^{11}$ and the third one are Vietnamese ${ }^{12}$. "The Vietnamese have primacy in living in the Czech Republic the longest - averagely eight years," reminds the analyst Yana Leontiyeva from the Institute of Sociology, Prague. On average, long-term immigrants from the former Yugoslavia live in the Czech Republic just

\footnotetext{
${ }^{9}$ Pořízková, H. Analýza zahraniční zaměstnanosti v České republice (p. 48)

10 Ministry of Interior.

1172000 in year 2011

12 about 61,000 in year 2011
} 
a year less. They are most often in their forties with secondary vocational education (51\%). Most college students come from Russia (27\% of immigrants). In terms of marital status, the majority of Vietnamese come with a partner, children or other family members. For example, Ukrainians tend to come with a partner, but the children are living outside the Czech Republic. Moldovans frequently come alone and only for work. Ukrainians send the most of their salaries to the country of their origin (17\% of income), followed by Moldovans (16\%) and Vietnamese (15\%). Almost half of the foreigners who are registered by labor offices are from Slovakia (49\%) followed by Ukrainians (16\%) and Poles (9\%).

\section{Regression analysis}

Regarding the analysis of the development of immigration into the Czech Republic and its influence on the economic environment of the Czech Republic there was created a regression and correlation analyses. These analyses are looking for the relationship among the immigration flows to the Czech Republic, GDP (bn. CZK), unemployment, salary, tax revenue and patents.

Table 3: Dependence on immigration

\begin{tabular}{|c|c|c|c|c|}
\hline & Patents & Tax Revenue (\%) & Growth of GDP (\%) & Wage \\
\hline \multirow[t]{2}{*}{ Migration } & 0.001 & -0.00001 & 0.000047 & -0.0000273 \\
\hline & $(3.19)^{* *}$ & $(1.43)$ & $(1.85)$ & $(2.05)$ \\
\hline \multirow[t]{2}{*}{ Unemployment (\%) } & & & 0.175 & \\
\hline & & & $(0.40)$ & \\
\hline \multirow[t]{2}{*}{ Wage $(\log )$} & & & -30.814 & \\
\hline & & & $(0.65)$ & \\
\hline \multirow[t]{2}{*}{ Tax Revenue $(\%)(\log )$} & & & 36.713 & \\
\hline & & & $(2.79)^{*}$ & \\
\hline \multirow[t]{2}{*}{ _cons } & 88.241 & 14.509 & 39.245 & 85.062 \\
\hline & $(4.77)^{* *}$ & $(45.89)^{* *}$ & $(0.20)$ & $(144.42)^{* *}$ \\
\hline$R^{2}$ & 0.39 & 0.11 & 0.46 & 0.20 \\
\hline$N$ & 18 & 18 & 18 & 19 \\
\hline
\end{tabular}

$* p<0.05 ; * * p<0.01$

Source: Own proceeding based on OECD data.

Table n. 3 demonstrates the results of regression analysis of four selected variables. The biggest positive correlation was proven between the influx of migrants and the number of issuing patents. This variable was included in the research because of the biggest inflow of the low-skilled migrants into the Czech Republic. The analysis shows that the arrival of each migrant with no change of other variables leads to expansion in the area of research. More specifically, the probability of obtaining a patent for a new invention will increase by $0.001 \%$. The research also shows that since the flow of the immigrants to the Czech Republic consists mainly of low skilled people, the Czech Republic is missing the 
possibility of growth in innovations. The possible solution could be to increase a salary which would attract the migrants with higher education and thus increase the area of innovation.

According to Grogger and Hanson (2008), more skilled emigrants usually migrate to places where the wages are higher, and that is why migrants choose particular major or big cities, with the higher salaries. Countries in which the salary of a skilled worker is relatively big are attracting a disproportionate share of more educated immigrants. In the United States and Canada, the income gap between high-skilled and unskilled workers is much higher than in continental Europe. USA and Canada receives 51.4\% of immigrants from countries of the OECD which is $65.5 \%$ of its immigrants with a tertiary education. Europe, in contrast, has $38.4 \%$ of immigrants from OECD countries, but only $23.6 \%$ of them in the tertiary sector.

Figure 7 shows the relationship of migration and the growth of GDP based on data from the OECD. The analysis demonstrated the positive impact of migration on GDP growth. The only exception is a year 2009, which was affected by the economic crisis. We must emphasize, however, that the impact of migration on GDP is so small that we cannot talk about the possibility of influencing this variable by increasing the other one. For example, when we look at the year 2002, GDP growth was about $1-2 \%$, but the migration was relatively low (40,000 immigrants). The analysis showed that in the Czech Republic, the GDP is not noticeably affected by the number of immigrants coming into the country. For a deeper analysis it would be necessary to track a longer time period, but in the case of the Czech Republic it is not possible since the statistical offices have data only since 1995.

Figure 7: Impact of migration on GDP growth

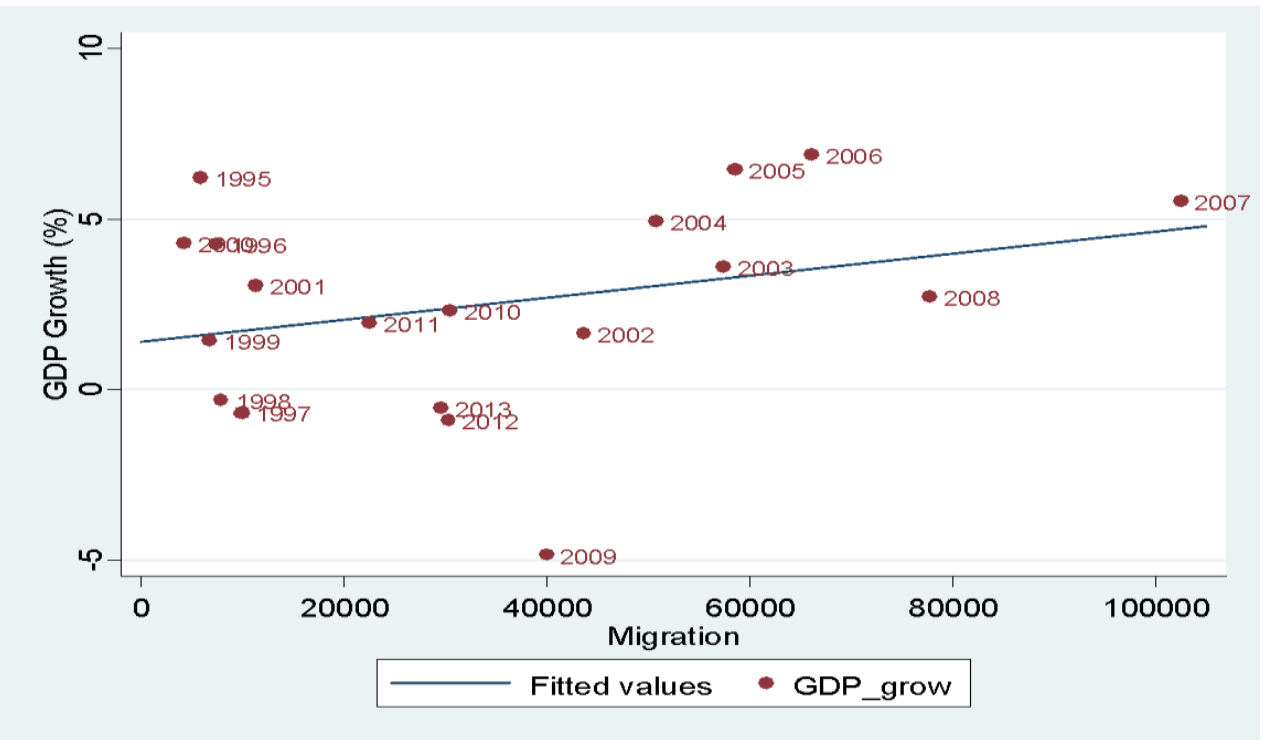

Source: Own proceeding based on OECD data. 
Figure 8 shows the impact of migration on wages. The analysis showed the negative impact of migration on wages. It can be claimed that the low-skilled immigrants might reduce the average wages for low-skilled Czech workers. In comparison to the impact of migration on GDP growth, the impact of migration on wages is negative but again not strongly correlated. There are a few outliers in the figure, such as year 1997, 2007 and from 2010 - 2013, which can lead to misleading interpretations and therefore it would be useful to study this issue further.

In the Czech Republic it was found out that the influx of migrants slightly decreases the average salaries for low-wage assessments, and thus has a negative impact on the salaries of Czech citizens. This is debatable, since it mainly concerns the areas with low wage rate, since the most migrants currently work on these positions. Furthermore, as Drbohlav (2014) stated, the Czech citizens would not work on these positions and therefore it does not significantly affect the level of wages for Czech citizens.

\section{Figure 8: Impact of migration on wages}

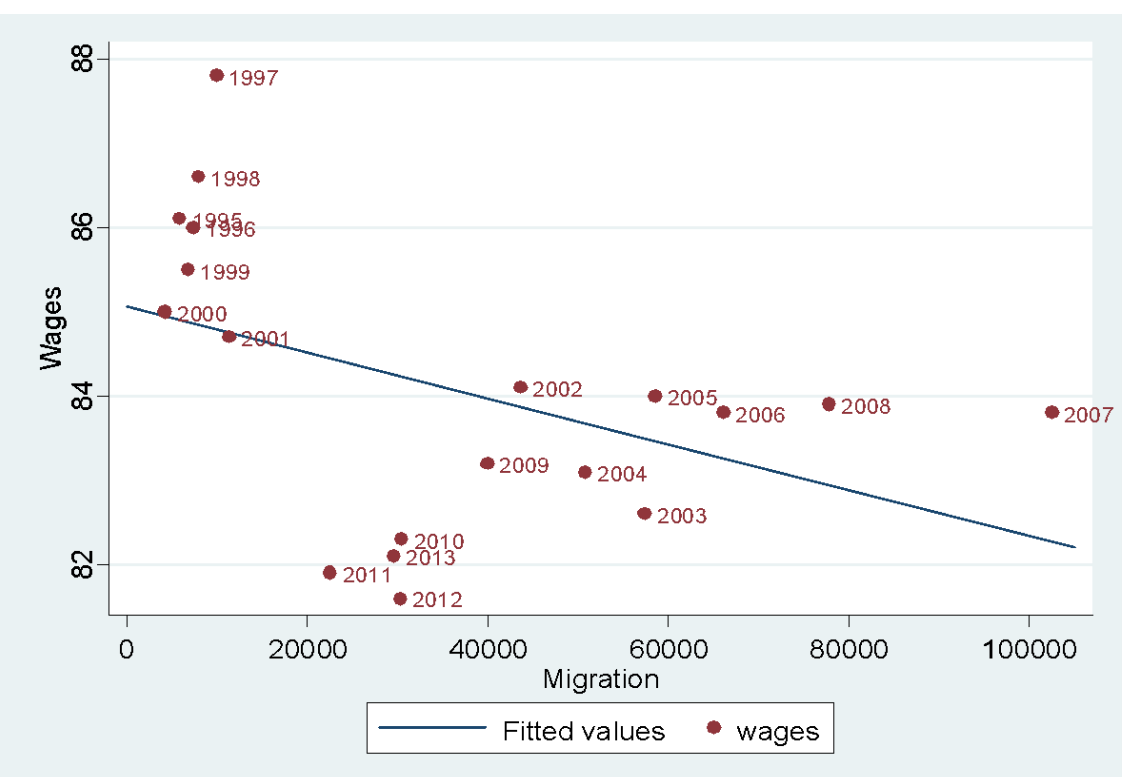

Source: Own proceeding based on OECD data.

Another analyzed variable was the tax revenue (\%). Analysis proved that migration can have a negative impact on tax revenues (\%). The results showed that migration and tax revenue (\%) are slightly negatively correlated to each other. 
Figure 9: Influence of migration on tax revenue (\%)

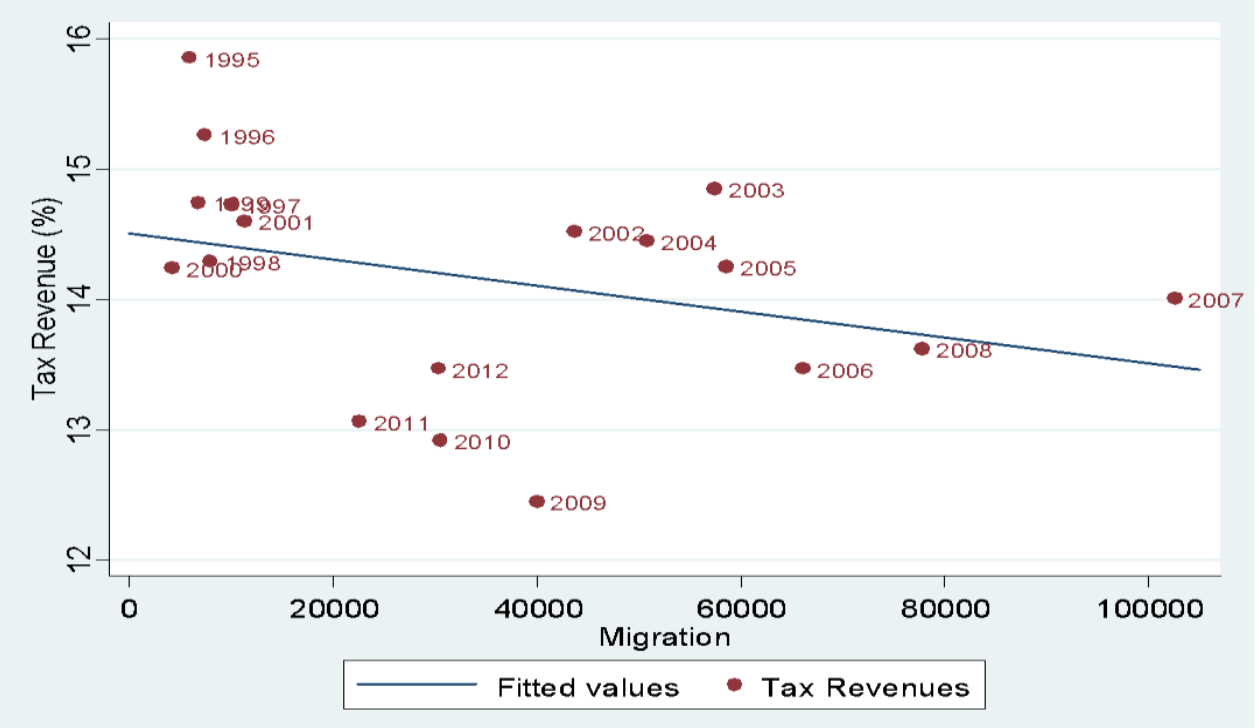

Source: Own proceeding based on OECD data.

Other examined variables were the patents and its influence on the migration. It was proven that migration has a positive impact on innovation. Although there are no definitive statistics on what kind of labor immigrants are coming to the Czech Republic (low qualified, high qualified) it can be concluded that the Czech Republic give the employment to a small proportion of highly qualified migrants. This assertion is furthermore endorsed by the results of the subsequent correlation analysis. Furthermore, Hunt (2011) proved that native Czechs devote more care of their education than incoming migrants and therefore the migrants mostly occupy less skilled positions.

Figure 10: Impact of migration on growth of innovation

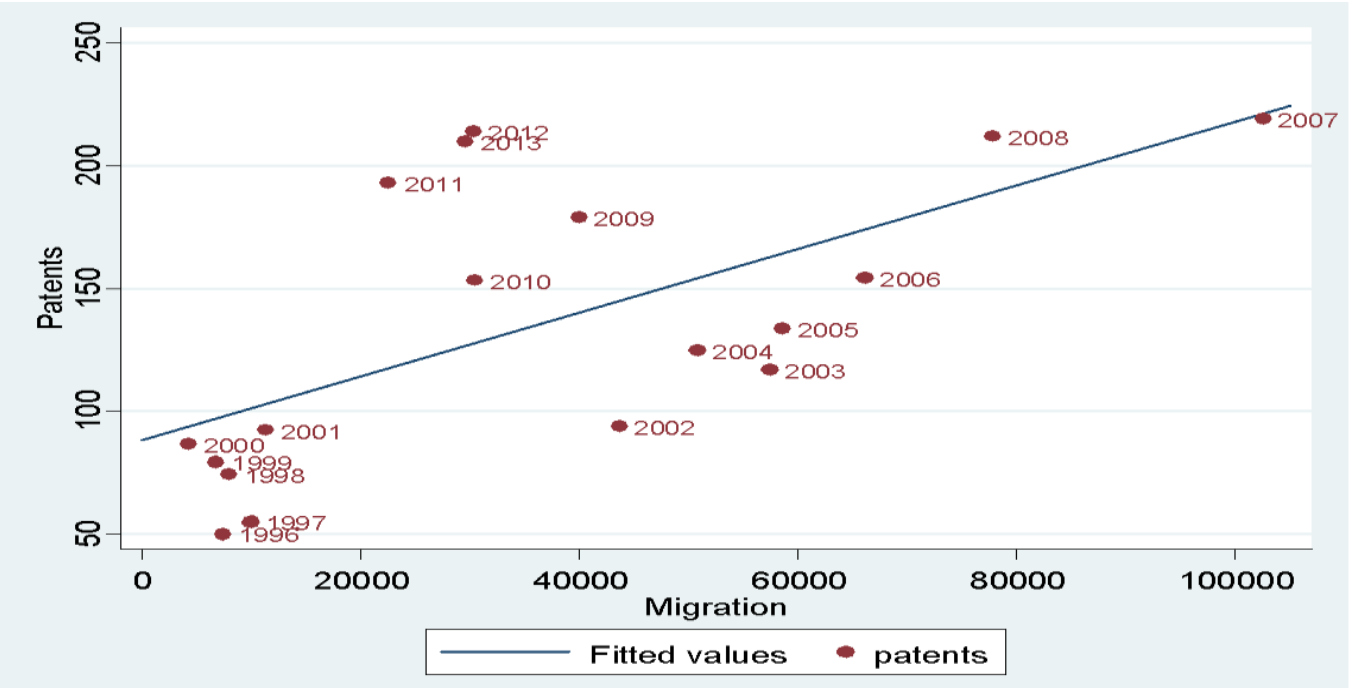

Source: Own proceeding based on OECD data. 


\section{Correlation Analysis}

The following correlation analysis of all four selected variables aims to reinforce the results of the regression linear analysis. The analysis showed that the correlation between innovation and the migration is 0.6235; which shows that among examined areas there is a moderate positive relationship. This can also be seen in the figure 10 . The analysis says that the influx of immigrants increases the area of innovation and thus have a positive effect on the area of science and research.

\begin{tabular}{r|ll} 
& patents migrat $\sim \mathrm{n}$ \\
\hline patents & 1.0000 & \\
migration & 0.6235 & 1.0000
\end{tabular}

Another examined relationship was the correlation among wages and migration which was proved negative. With the result -0.4459 , we can say that there is a weak and negative linear relationship. This result corresponds to the regression analysis.

\begin{tabular}{r|rr} 
& \multicolumn{2}{|c}{ wages migrat $\mathrm{n}$} \\
\hline wages & 1.0000 & \\
migration & -0.4459 & 1.0000
\end{tabular}

The third examined relationship was the correlation between tax revenues (\%) and migration where was proved a negative relationship -0.3366 . The figure shows that by the numerous number of outliers. Thus, the analysis showed that the increase in the number of migrants will decrease tax revenues. The relationship was proved to be relatively weak, and as was mentioned in the linear analysis, the results were reflected primarily in low-skilled positions.

\begin{tabular}{r|rr} 
& taxrev $\sim$ migrat $\sim \mathrm{n}$ \\
\hline taxrevenues & 1.0000 & \\
migration & -0.3366 & 1.0000
\end{tabular}

The correlation analysis of unemployment and migration showed that these variables are at the border of the nonlinear relationship. The measured value of -0.0617 almost does 
not testify either a positive nor negative relationship between migration and unemployment.

\begin{tabular}{r|rr} 
& unempl t migrat $\sim \mathrm{n}$ \\
\hline unemployment & 1.0000 & \\
migration & -0.0617 & 1.0000
\end{tabular}

If we look at the overall correlation of all variables with each other, the highest positive correlation is between innovation and migration, and the highest negative correlation is between migration and wages. From the complete analysis can be stated that the growth of migration affects the most positively the area of innovation and the most negatively the wages.

\begin{tabular}{r|rrrrrr} 
& gdp_grow migrat $\sim \mathrm{n}$ unempl $\sim \mathrm{t}$ & wages taxrev $\sim$ patents \\
\hline gdp_grow & 1.0000 & & & & & \\
migration & 0.4009 & 1.0000 & & & & \\
unemployment & 0.1311 & -0.1912 & 1.0000 & & & \\
wages & -0.0626 & -0.4400 & -0.2967 & 1.0000 & & \\
taxrevenues & 0.3566 & -0.2519 & -0.0102 & 0.6076 & 1.0000 & \\
patents & -0.0242 & 0.6796 & -0.1316 & -0.7588 & -0.7442 & 1.0000
\end{tabular}

\section{Discussion}

Based on the long-term development of the migration balance ${ }^{13}$, an abundant influx of immigrants can be expected in coming years. However, the slight fall in the number of immigrants can be predicted due to the expected slowdown of the Czech economy. The stated assumption can be bolstered by the proven correlation between the development of foreign workers in the Czech Republic and the economic cycle ${ }^{14}$.

Regarding the Czech Republic's accession to the Schengen area, where there are no controls on the shared borders thus people can cross the borders anytime and anywhere, there is a possibility of the extension of the illegal employment of foreigners. Illegal migration, which is currently a serious problem in many countries, brings undesirable effects in the form of enlarging the shadow economy, decreasing revenues for public

\footnotetext{
${ }^{13}$ According to which the Czech Republic can be characterized as an immigration country.

14 TURKOVÁ, V., PAVEL, J. Zaměstnanost cizinců v ČR (P.10)
} 
budgets through taxes and contributions to the social system, the expansion of crime, xenophobia, etc.

Asylum seekers come mostly from Afghanistan, Iraq, Turkey, the Federal Republic of Yugoslavia, the Russian Federation, Iran, Somalia, Bosnia and Herzegovina, Algeria and India. Europe refugee status, under the Geneva Convention in 1995-1999, was granted to about 200000 asylum seekers out of a total of 1.6 million applications. 1.1 million was rejected. Around 228000 were granted asylum for humanitarian and other reasons. In Europe, the average percentage of granted refugee status ${ }^{15}$ ranged between $2-6 \%$ of the submitted. Individual states, however, differ considerably in the percentage. It can be claimed that the Europe's approach to asylum seekers is based on the above mentioned - the most of them are rejected and this also applies in the case of the Czech Republic.

\section{Conclusion}

International labor migration heading to the industrially developed countries of Central, Western and Northern Europe, was characterized ${ }^{16}$ by mostly intra-European population movements. Foreign workers either entered the country unorganized with the work permits or through organized recruitment called Gastarbeiter system (guestworker systems).

The arrival of family members in Europe is becoming one of the most important forms of immigration, similarly as in the US. The second biggest reason are the preferential migration ties, still partly in the form of post-colonial immigration after the fall of the Iron Curtain. The third area consists of international, global, and labor migration within which can be distinguished two areas - migration experts and elites and the often temporary stay of certain categories of workers in certain professional fields.

After the fall of the Iron Curtain the European companies began to expand its reach. It was possible to identify an increased exodus of technical experts to the west amounting to a "brain drain" that soon caused a problem for the economic future of "reforming states." The migration of elites also includes international mobility of artists and scientists, migration for education and qualifications as well as traveling of embassy personnel, consulates and international organizations. Workers from "third countries", who came under bilateral agreements and gained a limited entry permit through the EU's external borders, move on the basis of the social pyramid of labor migration. In the context of labor migration, the Czech Republic has long-term experience with the temporary migration from east to west, particularly the seasonal migration that is related to seasonal farm work and construction. The fourth major area of legal immigration to Europe include

\footnotetext{
15 under the Geneva Convention in the nineties

${ }^{16}$ until the fifties of the 20th century
} 
refugees and exiles, regarding the political asylum or temporary stays with different refugee status. The last area is the least experienced in the Czech Republic.

However, there is an increasing flow of international migrants, and among them asylum seekers. Predominant direction of migration flows is from east to west and from the poorer countries to the developed countries, especially to the EU countries.

In this respect, the Czech Republic does not differ from global trends. After 1990, the countries of Central and Eastern Europe, especially Poland, Hungary and the Czech and Slovak Republic became a buffer zone for immigrants and it is expected that the number of immigrants will develop in the same direction as before.

Regression and correlation analysis demonstrated that migration has the most powerful effect in the areas of innovation and wages (in the case of the Czech Republic). The strongest positive correlation was demonstrated between migration and innovation and the strongest negative relationship between migration and wage levels. The analysis also showed that GDP is almost negligibly influenced by the arrival of migrants and hardly affect the growth rate of this indicator.

\section{References}

BAŠTÝŘ, I. A KOL. Sociální důsledky vstupu České republiky do Evropské unie. 1 Kyd.. Brno: Masarykova Univerzita v Brně, 2005. 334 s. ISBN $80-210-3722-9$.

BARŠOVÁ, A., BARŠA, P. Přistěhovalectví a liberální stát. 1. kyd. Brno: Masarykova Univerzita v Brně, Mezinárodní politologický ústav, 2005. 308 s. ISBN 80 - 210 - 3875-6.

BORJAS, G. J. 2001. Does Immigration Grease the Wheels of the Labor Market? Brookings Papers on Economic Activity. Pp. 69-119. http://dx.doi.org/10.1353/eca.2001.0011

BURCIN, B. DRBOHLAV, D. A KUČERA, T. Možnosti migračního řešení perspektivního úbytku a demofigurei ckého stárnutí obyvatelstva České republiky. Sociologický ústav AV ČR, v.v.i., Praha 2008. B.

CASELLI, G. a VALLIN J. a WUNSCH G.J. Demofigurey: Analysis and Synthesis. Boston: Elsevier, 2006. ISBN 978-0127656601, s. 94

CASTLES, S.: Understanding Global Migration: A Social Transformation Perspective, Journal of Ethnic and Migration Studies, 36, 2010, č.10, s.1565-1586.

ČERVEŇÁKOVÁ, O. Trestní aspekty nelegální migrace. Závěrečná práce. Masarykova Univerzita. Katedra trestního práva. Rok 2008.

ČESKÁ LÉKAŘSKÁ SPOLEČNOST. Revmatoidní artritida In: Doporučené postupy pro praktické lékaře [on-line]. Praha: ČLS, @ 2016 [vid. 2016-01-10]. Available: http://www.cls.cz/seznam-doporucenychpostupu

ČESKÝ STATISTICKÝ ÚŘAD. Cizinci - zaměstnanost, 10 nejčetnějších zemí. Available: http://www.czso.cz/csu/cizinci.nsf/tab/C900558ABD. 
ČESKÝ STATISTICKÝ ÚŘAD. Trvale a dlouhodobě usazeni cizinci v ČR (1995 - 2012). Available: http://www.czso.cz/csu/cizinci.nsf/tabulky/ciz_pocet_cizincu-001\#.U3B35VcyB55.

DAVIS, T. - HART, D. M. 2010. International Cooperation to Manage High-Skill Migration: The Case of India-U.S. Relations. Review of Policy Research, 27, pp. 509-526. http://dx.doi.org/10.1111/j.15411338.2010.00454.x

DEMOFIGUREIE Migrace [online]. c 2004 - 2008 [cit. 2014-06-05]. Available: http://demofigureie.info/?cz_migrace.

DE HAAS, H.: Migration and Development: A Theoretical Perspective. International Migration Review, 44, 2010, n.1, p.227-264.

DE JONG, G. F. A GARDNER, R.W. Migration decision making: multidisciplinary approaches to microlevel studies in developed and developing countries. New York: Pergamon Press, 1981. ISBN 0080263054 , p. 17

DRBOHLAV, D.: Hlavní trendy mezinárodní migrace. Demofigureie, 1995, year 37, p. 4.

DRBOHLAV, D. A KOL. Migrace a rozvoj. Rozvojový potenciál mezinárodní migrace. Praha 2011. UK Praha. ISBN 978-80-87404-10-2.

FRANC, A. Hlavní tendence ve vývoji pracovních migrací v České republice. Centrum výzkumu konkurenční schopnosti České republiky [online]. May 2014 [cit. 2014-05-20]. Available: http://is.muni.cz/do/1456/soubory/oddeleni/centrum/papers/wp2006-22.pdf.

GUARNIZO ET AL., 2003. Assimilation and Transnationalism: Determinants of Transnational Political Action among Contemporary Migrants. University of California. Available: http://www.ssrc.org/workspace/images/crm/new_publication_3/\%7Bce43828a-3455-de11-afac001cc477ec70\%7D.pdf

HANSON, G. H. The economic consequences of the international migration of labor. Working Paper 14490. National bureau of economic research. Cambridge 2008. Available: http://www.nber.org/papers/w14490.pdf

HOLMAN, R. Ekonomie. Praha: Publisher C. H. Beck, 2011. ISBN 978-80-7400-006-5, p. 322.

HORÁKOVÁ, M. Cizinci na trhu práce v České republice v letech 1994 - 2004. Výzkumný ústav práce a sociálních věcí. Available: www.vupsv.cz.

HORÁKOVÁ, M. Zpráva o vývoji pracovních migrací 1993-2006. Výzkumný ústav práce a sociálních věcí. Available: www.vupsv.cz.

KHOO, S.E., HUGO, G., MCDONALD, P. 2010. Skilled Migration from Europe to Australia. Population, Space and Place, 16, pp. 550-566. http://dx.doi.org/10.1002/psp.651

KHOO, S.-E., MCDONALD, P., VOIGT-FIGURE, C., HUGO, G. 2007. A Global Labor Market: Factors Motivating the Sponsorship and Temporary Migration of Skilled Workers to Australia. International Migration Review, 41, pp. 480-510. http://dx.doi.org/10.1111/j.1747-7379.2007.00076.x

MASSEY, D.: Economic Development and International Migration in Comparative Perspective. Population and Development Review, 14, 1988, n.3, p. 383-413.

MASSEY, D. Geofigureiska Annaler: Series B, Human Geofigurey. Volume 86, Issue 1, pages 5-18, March 2004.

POŘíZKOVÁ, H. Analýza zahraniční zaměstnanosti v České republice; postavení. Výzkumný ústav práce a sociálních věcí. Available: www.vupsv.cz. 
PORTES, A. A DEWIND, J. Rethinking migration: new theoretical and emperical perspectives. New York: Berghahn Books, 2007, vi, 440 p. ISBN 978-1-84545-543-9.

PORTES, A., BACH. R.L. 1985. Latin Journey: Cuban and Mexican Immigrants in the United States. Berkeley, CA: University of California Press.

PROCHÁZKOVÁ ILINITCHI, C. Migration policy as a precondition for a common labor Market in the european union. ACTA OECONOMICA PRAGENSIA. 2014

$\begin{array}{lllll}\text { Slovníček základních pojmů } & \text { [online]. } & \text { [cit. 2014-05-17]. } & \text { Available }\end{array}$ <http://vyuka.jazyku.cz/i/File/Slovn\%C3\%ADk_MKC_k\%20MKV.txt>.

STOJANOV, R. STRIELKOWSKI, W. ET DRBOHLAV, D. Pracovní migrace a remitence: současné trendy $v$ době ekonomické krize. Rok 2011. Available: http://geofigurey.cz/sbornik/wpcontent/uploads/2012/01/g11-4-1stojanov_strielkowski_drbohlav.pdf

STOJANOV, R. A NOVOSÁK, J. Migrace místo pomoci? Remitence a cirkulace mozků jako nástroje rozvoje. Year 2008. Mezinárodní vztahy, 43 (1). ISSN 0323-184.

STRAUBHAAR, T.: Migration Pressure. International Migration - Quarterly Review. 1993, v.31, no. 1, p.542.

TURKOVÁ, V., PAVEL, J. Zaměstnanost cizinců v ČR. Výzkumná studie Ministerstva financí České republiky [online]. June 2007 [cit. 2014-05-15]. Available: http://www.mfcr.cz/cps/rde/xbcr/mfcr/Zamestnanost_cizincu_vCR_pdf.pdf.

VÁVRA, J. Migrace (nejen za prací). [online]. 10.5.2014 [cit. 2014-06-20]. Available http://people.tul.cz/ jaroslav.vavra/GEOGR/MIGRACE.pdf

VLÁDA ČESKÉ REPUBLIKY. Aktualizovaná Koncepce integrace cizinců Společné soužití. Year 2011. Available: http://www.mpsv.cz/files/clanky/19016/Koncepce_integrace_cizincu_Spolecne _souziti.pdf

WINKLER, J., ŽIŽLAVSKÝ, M. KDS. Český trh práce a Evropská strategie zaměstnanosti. 1. Kyd.. Brno: Masarykova univerzita v Brně, 2004. 241 p. ISBN $80-210$ - 3565 - X.

WILLEKENS, F. 1993. Monitoring International Migration Flows in Europe. Towards a Statistical Data Base Combining Data from Different Sources. International Institute for Applied Systems Analysis: Working Paper WP-93-051.

ZAPADLO, J. Krátkodobá ekonomická migrace do Španělska. Diplomová práce. Univerzita Pardubice. Year 2010.2 Available: https://dk.upce.cz/bitstream/handle/10195/37342/diplomov\%C3\%A1\%20pr\%C3\%A1ce.pdf?sequenc $\mathrm{e}=1$ \&isAllowed $=\mathrm{y}$

ZOLBERG, A. R., LONG LITT WOON. 1999. Why Islam is like Spanish: Cultural Incorporation in Europe and the United States. Politics \& Society 27 (1): 5-38. http://dx.doi.org/10.1177/0032329299027001002 